\title{
TECTONICS AND MINERALIZATION IN SRI LANKA
}

\author{
P. W. VITANAGE
}

VITANAGE, P. W., 1985: Tectonics and mineralization in Sri Lanka. Bull. Geol. Soc. Finland 57, Part 1-2, 157-168.

Over nine-tenths of Sri Lanka is underlain by Precambrian metasedimentary rocks, granitic gneisses and migmatites. The Highland Series (granulite facies), made up of typical metasedimentary rocks - quartzites, marble, white granulites and granulitic gneisses - along with charnockites and migmatites, occupies the central parts of the Island. The more argillaceous members of this series in the southwest are called the Southwest Group, with garnet-sillimanite-graphitegneisses, garnetiferous schistose rocks, marble, wollastonite-scapolite rocks and more basic charnockites. The rocks of the Highland Series are rich in mineral deposits.

The younger Vijayan Series (almandine-amphibolite facies), consisting of microcline hornblende migmatitic gneisses, hornblende gneisses and calc-gneisses, occupies the northeast and east. The eastern Vijayan rocks in the northwest are predominantly pink-feldspar hornblende granites and granitic gneisses. These rocks are poor in mineral resources.

The tectonic and structural pattern of the two Series differs considerably. The rocks of the Highland Series have been thrust into a series of anticlinal and synclinal structures, locally overturned and sheared, elongated domes and basins. Some of the commercially exploited minerals, e.g. graphite, are associated with the anticlinal structures, foliation joints and local lineaments in these structures. The rocks of the Vijayan Series, with their scarcity of economic minerals, show a marked contrast to the tectonic patterns of the Highland Series. The Vijayan rocks often exhibit irregular, albeit commonly oriented, E-W trends with steep foliation. Circular dome structures resembling igneous intrusions occur locally. These domes may prove to be potential sites for mineralization.

Both these Series as well as the younger sediments - Jurassic deposits in the northwest and Miocene rocks in the north-northwest coastal belt and south-southeast - are intersected by a series of deep and shallow lineaments of Pre-Gondwana and Post-Gondwana times. Deposits of basemetals, copper and magnetite towards the northeast and along the western lowlands seem to be closely associated with some of these thrust or graben lineaments. The potential importance of these lineaments for basemetals, oil and gas and the tectonic control of the graphite deposits are discussed in the present paper.

Key words: structure, lineaments, arenas, mineralisation, tectonics.

P. W. Vitanage: Department of Geology, University of Peradeniya, Peradeniya, Sri Lanka. 


\section{Introduction}

With the exception of graphite, placer deposits of gems and rare earth minerals, and mineral sands such as ilmenite, rutile, monazite and zircon, Sri Lanka is not rich in commercially exploitable mineral deposits (Fig. 1). However, the old historical chronicle, the Mahawansa, refers to the occurrence of gold, silver, copper and iron in commercial quantities on the Island. The art of smelting ores for copper, silver and gold has been known to Sri Lankans for over 2000 years. Iron and steel weapons including swords have been manufactured from time immemorial from local raw materials. Sri Lanka steel had a fine reputation in mediaeval times and was exported to Damascus. Although graphite was known to occur in Sri Lanka, it is only within the last 160 years that it has been systematically mined.

The results of a detailed mineralogical survey by Coomawaswamy (1903-1905) showed that the Precambrian of Sri Lanka is rich in important strategic minerals - monazite, zircon, iron-ore and copper. Over twenty minerals ranging from thorianite to platinum were discovered during this mineral survey. An occurrence of molybdenite in present day Kegalle District was known in 1843 and was rediscovered in 1905 . This five to six foot wide pegmatite at Hettimulla was extensively worked by German prospectors until the outbreak of the Second World War (Fig. 1).

More recently commercial quantities of copper, magnetite, apatite and serpentine have been discovered by the Geological Survey (Seruwavila Copper-magnetite find, 1971) and by the Department of Geology, University of Peradeniya (Victoria copper-silver prospect, Vitanage 1980). With the exception of the geology and tectonics of the graphite mines, no detailed surveys of the mineral deposits other than the offshore oil prospects, the copper-magnetite find at Seruwavila, the apatite at Eppawala, the peat at Muthurajawela and the Boralasgamuwa kao- lin, have been carried out to date.

The period since the 1970s has seen a large number of extensive off-shore seismic surveys (USSR, 1973-74; Ceyoil Corporation, 1974), intensive deep-drilling, off-shore gravity surveys of sediments from the Jurassic, Cretaceous and Miocene to Recent and less intensive gravity surveys of the whole Island. The availability of satellite imagery (Landsat) and the study of the major lineaments in the hydro-engineering project areas have demonstrated the importance of structure, lineament and plate tectonics to the potential mineralization pattern in Sri Lanka (Fig. 1). The influence of tectonics on the occurrence and distribution of mineral deposits with special reference to graphite, copper, magnetite and oil and also to groundwater will be discussed in the following sections.

\section{General geology}

Over two-thirds of Sri Lanka is underlain by Precambrian rocks (1000 m.y. -2500 m.y.) which are divided into two groups, the Highland and Vijayan Series. The Highland Series (granulite facies) consists of a succession of typical metasedimentary rocks - quartzites, marble, white granulites and granulitic gneisses, charnockite granites and gneisses, garnet-sillimanite - graphite-gneisses, garnet-biotite gneisses (leptynites) and biotite gneisses. Around Kandy, within the Highlands there is a series of arenas (morphological synclinal basins) underlain by migmatites (hornblende-microcline-gneisses) resembling the migmatites of the Vijayan Series (Vitanage 1972).

The argillaceous rocks of the Highland Series around Ratnapura, Panadura and Galle consist of more feldspathic and garnetiferous rocks, and the wollastonite and scapolite rock - the Galle Series of Adams (1929) - are included in the Southwest Group by some geologists. Charnockites (basic types) and cordierite gneisses are extensively developed around Panadura and Homagama (Fig. 1). 
Tectonics and mineralization in Sri Lanka 159

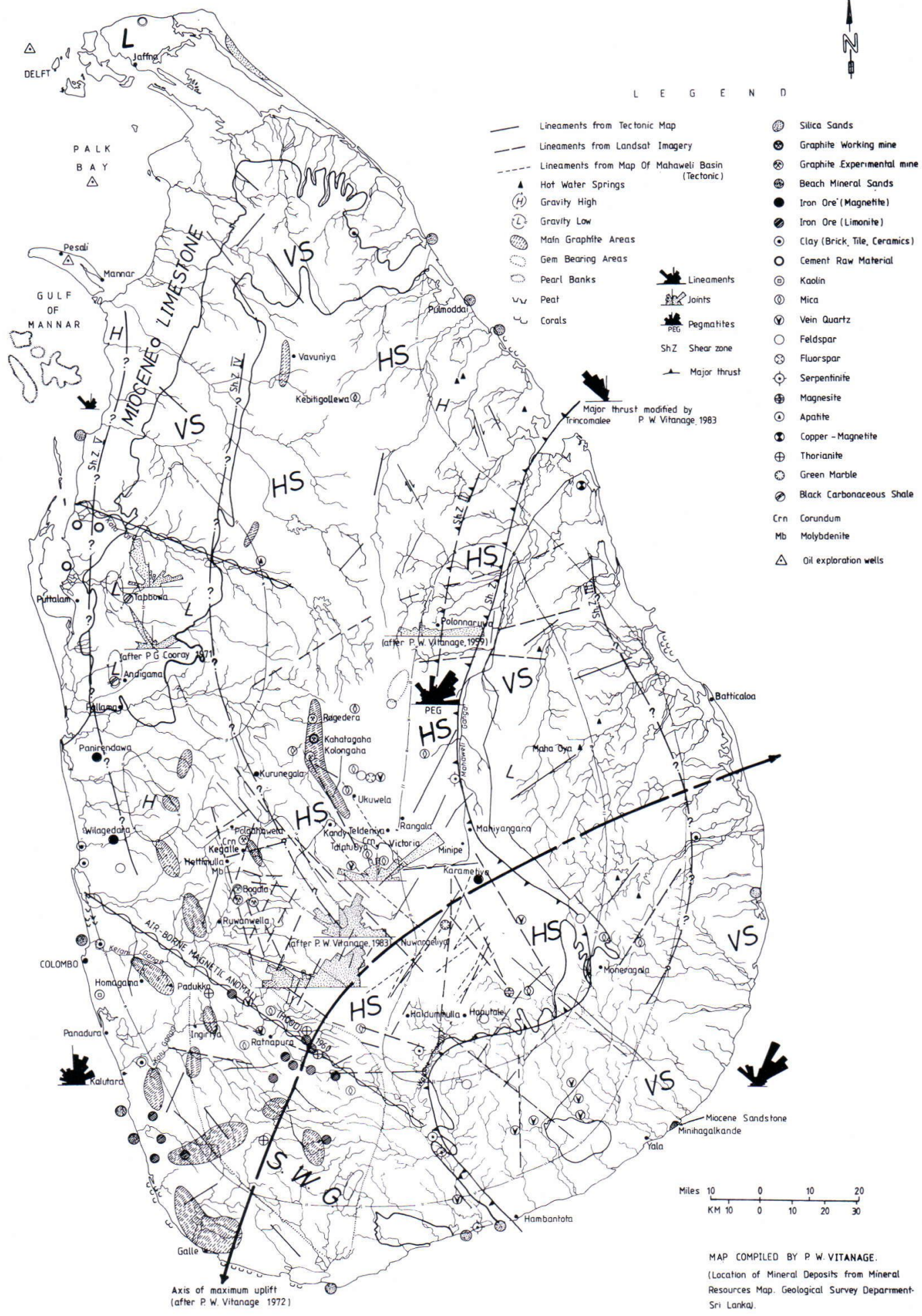

Fig. 1. Tectonics and Mineral Deposits in Sri Lanka. 
The young Vijayan Series (almandine-amphibolite facies) consists mainly of migmatitic microcline-hornblende-biotite-gneisses and calc-gneisses. Marble and quartzites are rare. These Vijayan rocks occupy the eastern and southeastern lowlands and uplands. The nortwestern Vijayan rocks are characterized by the occurrence of pink-feldspar-hornblende granites (Tonigala type) and gneisses. The Vijayan Series rocks are generally barren of economic minerals (Fig. 1).

The younger rock groups - the Jurassic sandstone (arkosic) shales, siltstones and conglomerates - are preserved in faulted basins near Tabbowa, Andigama and Pallama in northwestern Sri Lanka. Miocene limestone occupies the Jaffna Peninsula and the surrounding islands and extends along the northwestern coastal lowlands as far south as Puttalum. Narrow outcrops of Miocene sandstone are found in the SSE, near Minihagalkanda, Yala (Fig. 1).

\section{Structure}

The Precambrian metasedimentary rocks of the Highland Series have been thrust into a series of anticlinal and synclinal structures, canoe-shaped basins (arenas) and elongated domes which apparently form a broad northplunging anticlinorium occupying the centre of the Island from Galle to Trincomalee (Fig. 1). Three dominant structural trends can be recognized in the well-developed strike ridges of the Highland Series: (i) NW-SE to NNW-SSE (Taprobanian trend) in the southwestern sector, (2) N-S to NE-SW in the north and northeast, (3) E-W and NE-SW swing of the fold axes in the southwestern upland and highland areas. As shown in later sections, some of the structures have influenced the localization of minerals, e.g. graphite and mica (Fig. 2 and 3).

In marked contrast to the tectonic pattern of the Highland Series, the younger migmatite microcline biotite-gneisses of the east and south- east and the pink-feldspar hornblende and granite gneisses in northwestern Sri Lanka show characteristically irregular though commonly oriented E-W trends with steep foliations. Strong dome-like arcuate structures suggesting igneous intrusions have developed locally. Although the Vijayan Series is barren of economic minerals, mineralization may occur along old lineaments and around igneous intrusions.

\section{Tectonics and fracture pattern}

Geological mapping and photo-geological and satellite imagery studies have indicated a series of major lineaments both regional and local (Fig. 1). Morphologically, geologically and geophysically the most well-defined megalineaments (probably a major Precambrian thrust zone; Hatherton 1975) is Mahaweli Shear Zone I, which extends from the Trincomalee submarine canyon (over $3300 \mathrm{~m}$ deep) in a gentle arcuate line for over $150 \mathrm{~km}$ along the Mahaweli river valley from Gallella to Maiyangana through Moneragala to Hambantota in the SSE (Fig. 1, Vitanage 1983). Mahaweli Shear Zone II (Vitanage 1959) is marked by augen and flaser gneisses and recumbent quartzite bands. No economic minerals have been found along this second thrust zone. The age of this lineament thrust $520 \pm 50 \mathrm{~m} . \mathrm{y}$. (Wilson and Shillibeer in Vitanage 1959, p. 59).

Bouguer gravity anomalies (Hatherton et al. 1975) indicate that two other similar thrusts could probably occur - one in the Vijayan along the steep gradient running down the east coast and the other, a deep fracture zone, along the nortwestern Vijayan contact and east of the Mannar-Puttalum high, continuing SSE towards Hatton west of the arenas near Kegalle (Fig. 1, Vitanage 1983).

In addition to these megalineaments, which are probably reactivated Pre-Gondwana linear fractures and thrusts there is another series of Post-Gondwana lineaments trending NNW- 
SSE, NNE-SSE, N-S and E-W. The lineaments, over $10 \mathrm{~km}$ long are shown on the Ceylon Tectonic Map (1960), in satellite imagery (Landsat 1) and on structural field maps (Vitanage, 1959, 1981, 1982 and 1983a). They are plotted in Fig. 1 along with the occurrences of mineral deposits (Geological Survey Map Mineral Deposits 1983) and orientation of joints and pegmatites on the Polonnaruwa sheet (Vitanage 1959), in the Polpitiya and Kotmale areas in central Sri Lanka (Vitanage 1981).

The recent gravity survey by Hatherton and his co-workers (1975) "designed to assess the use of geophysical methods for mineral prospecting, and enhancing geological exploration in Sri Lanka"' is a landmark in tectonic analysis and mineralization in Sri Lanka. The potential importance of these lineaments for future mineral exploration programmes will be discussed later.

\section{Mineralization and tectonic lineaments}

The location of mineral deposits in Sri Lanka has been plotted in Fig. 1, which shows the general geology, the lineaments, joints and pegmatites (two localities) and the distribution of mineral deposits. The relationship between tectonics and mineralization will be discussed in the following sections.

\section{Pegmatites and fracture pattern}

The occurrence and distribution of pegmatites in Sri Lanka has not been investigated in detail. However, the orientation of the pegmatites and the fracture pattern of the country rocks have been studied to a limited extent, in the course of geological mapping in some areas and along tunnels (Vitanage 1959, Vitanage 1968, Vitanage 1981). In the Polonnaruwa area, the distribution of pegmatites containing feldspar (potash and soda) quartz and mica, ranging in size from small veinlets two inches thick to larger bodies six to eight feet (1.5 to $2 \mathrm{~m}$ ) wide, seems to depend on the rock types. Pegmatites are more abundant in the charnockite-biotite gneiss complex than in the quartzite and marble. Apart from the pegmatites conformable with the foliation and minor folds in the migmatite garnetiferous granite gneisses, the pegmatites are vertical and dip steeply $55^{\circ}-85^{\circ}$. The most pronounced trend is $30^{\circ}-50^{\circ}$ with three other important trends at $0-10^{\circ}, 90^{\circ}$ and $140^{\circ}-$ $150^{\circ}$ (Vitanage 1959 , p. 53). An interesting feature observed in the field is the lateral displacement of the foliation of the host rock: dextral in pegmatites trending NW-SE and sinistral in those trending NE-SW.

Airphotos of the Polonnaruwa area reveal lineaments at $\mathrm{N} 10^{\circ}-30^{\circ} \mathrm{W}$ with dextral displacement of the quartzite beds approximately $0.5 \mathrm{~km}$ from Minneriya. Landsat imagery indicates prominent lineaments trending $\mathrm{N} 30^{\circ} \mathrm{E}$ and $90^{\circ}(\mathrm{E}-\mathrm{W})$. The strike pattern of the joints is $\mathrm{E}-\mathrm{W}\left(90^{\circ}\right)$ with two minor trends at $100^{\circ}-$ $110^{\circ}$ and $0^{\circ}-10^{\circ}$. These pegmatites with no economic minerals are probably controlled by cross-cutting shear zones and joint openings at depth (Fig. 1, rosettes, Polonnaruwa). The ages of the pegmatites could vary from 487 m.y. to 905 m.y. in the Polonnaruwa and Vakaneri areas (Crawford and Oliver, 1969, p. 287 and p. 291).

\section{Graphite}

As shown in Figs. 1, 2 and 3 there is strong evidence in Sri Lanka for structural and tectonic control of vein graphite mineralization as is proved by the studies of Silva (1974) and Wijenanda and Jayawardene (1983). During his mineral survey in the central parts of Sri Lanka Coomaraswamy observed in 1905 that the veins of graphite occur "'parallel to the foliation planes of granulites or country rocks and filling strike and dip joints.' Even when graphite occurs in pockets and not in regular veins, it is parallel to the strike or at right angle — probably 

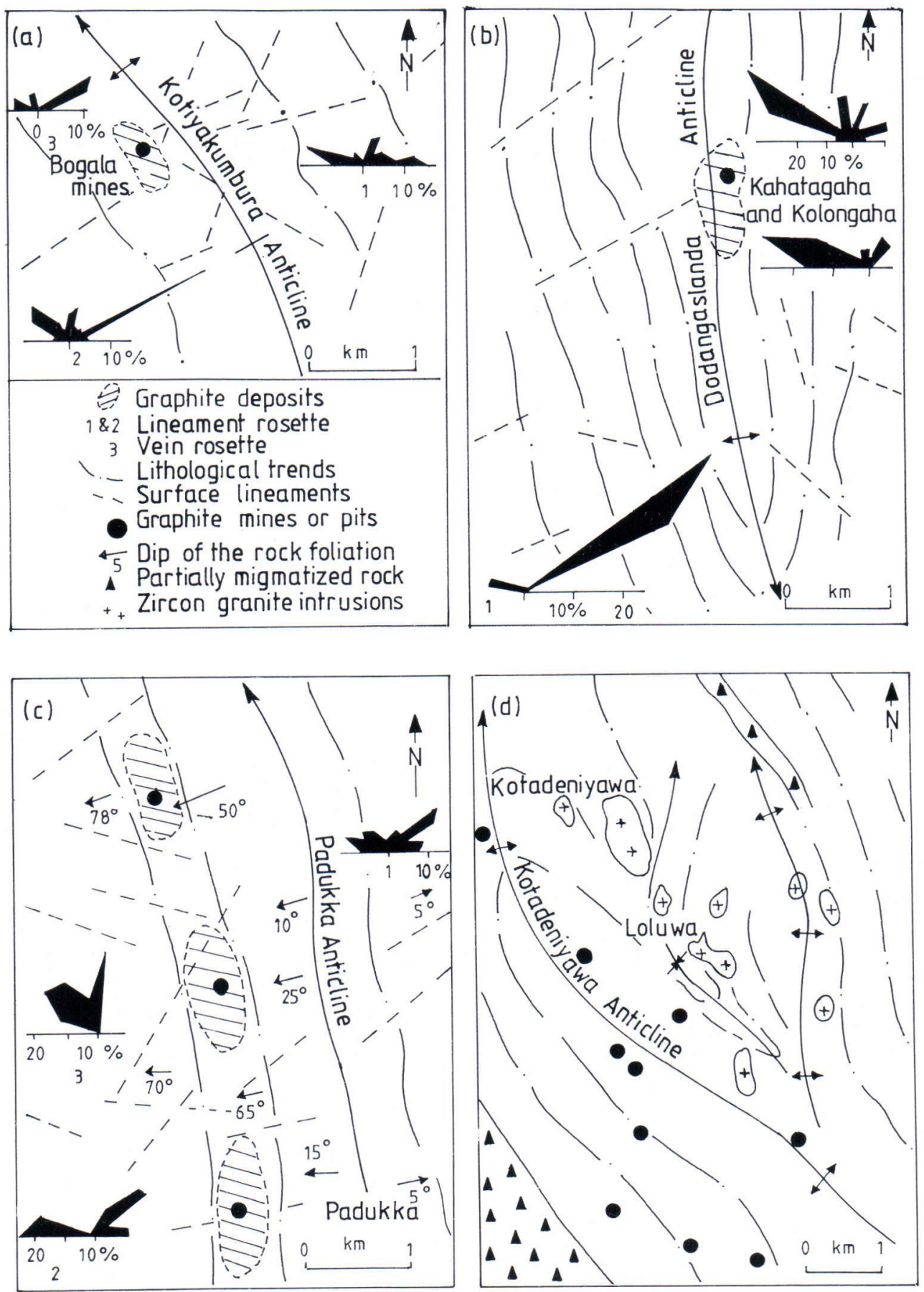

( after Silva 1974)

Fig. 2. Graphite deposits, structure and lineaments. 
following "'dip joints.' In 1906, referring to the Laxapana graphite mine, where graphite had been systematically mined and plans kept, Coomaraswamy commented that the nearly vertical, parallel veins do not extend for great distances laterally, being thin lenticles in form.

Wadia (1943) observed that the workable graphite deposits of Sri Lanka are the "'result of the filling of pre-existing fissures or cracks in country rocks or as intrusions in the form of pegmatite dykes," giving evidence of considerable pressure that moulded the graphite into a zone of sheared or disturbed rocks.

According to Wadia, the most prominent geological strike of the graphite belts in western Sri Lanka (the Southwest Group of Rocks) is NNW-SSE, parallel to the foliation strike of the granulites. But trends more to $\mathrm{E}-\mathrm{W}$ are also met with when graphite occurs along joints. In Galle and Kalutara Districts, this trend of the graphite deposits persists for over $60 \mathrm{~km}$ even though they are less than $750 \mathrm{~m}$ wide e.g. at Pasdun Korale, southwestern Sri Lanka (Figs. 1 \& 2).

Silva (1974) commented that in the main Highland Series, the graphite veins occur as tabular parallel members generally normal to the axes of the folds. Deposits in the more argillaceous metasediments of the Southwest Group occur along linear mineralized shear zones. These weins show two preferred orientations to the anticlinal structure, viz. in the convex region of the anticlinal limb, but not in the axial region of the fold. The orientation symmetry of the two vein patterns (dihedral angle varying from $40^{\circ}$ to $60^{\circ}$ ) is similar to that of the fractures and shear zones with a dihedral angle of $60^{\circ}-120^{\circ}$ (Fig. 2 C, Silva 1974, p. 4).

Graphite has not been observed along the megalineaments to date. However, the trend parallel to foliation referred to by Wadia (1943) is significant. At the site of the Kotmale dam and elsewhere, recent engineering geological mapping has revealed more recent shearing and movement parallel to the foliation (''foliation shears") with low-grade mineralization.

In southwestern Sri Lanka, the rocks are tightly folded and locally overturned. In some areas, thrusts associated with recumbent folds are common. Thus the tectonic setting in the southwest probably provided ideal conditions for graphite mineralization along the tectonic fractures and foliation shears similar to the tectonic features with graphite veins referred to by Wadia (1943) and Silva (1974).

\section{Graphite Mineralization - the Bogala and Kahatagaha mines}

Recent studies (Erdosh 1970, Silva 1974, Wijayananda and Jayawardene 1983) demonstrated clearly the structural and tectonic control of the graphite mineralization in the two largest graphite mines in Sri Lanka indeed in the whole world - Bogala near Kotiyakumbura (Kegalle District) and Kahatagaha near Kurunegala (Figs. 1, 2 and 3). At Bogala, where the major veins follow the general trend of the major fractures and lineament system of the Kotiyakumbura anticline (Erdosh 1970, Silva 19747, the graphite veins are relatively thicker than those at Kahatagaha (Figs. 2 and 3).

The results of the study of graphite veins at Kahatagaha and Kolongaha in Kurunegala District (Figs. 1 and 3) indicate that the graphite veins in Sri Lanka are of the hydrothermal fissure type intruded into a late joint system within the core of Precambrian metasedimentary antiforms (Wijeyananda and Jayawardene, 1983). In the Kahatagama mine which descends to 610 $\mathrm{m}$, the main graphite mineralization is confined to the centre of a north-south trending dome the double plunging Dodangaslunda anticline (Figs. 1, 2 b and 3). The veins trend eastwest, $\mathrm{N} 70^{\circ} \mathrm{W}$, and $\operatorname{dip} 85^{\circ}$, and are parallel to the major fractures and lineaments intersecting the crest region of the anticline (Figs. 2 b and 3; Silva 1974).

The Ragedara mine is located at the end of the regional dome structure. The graphite veins 


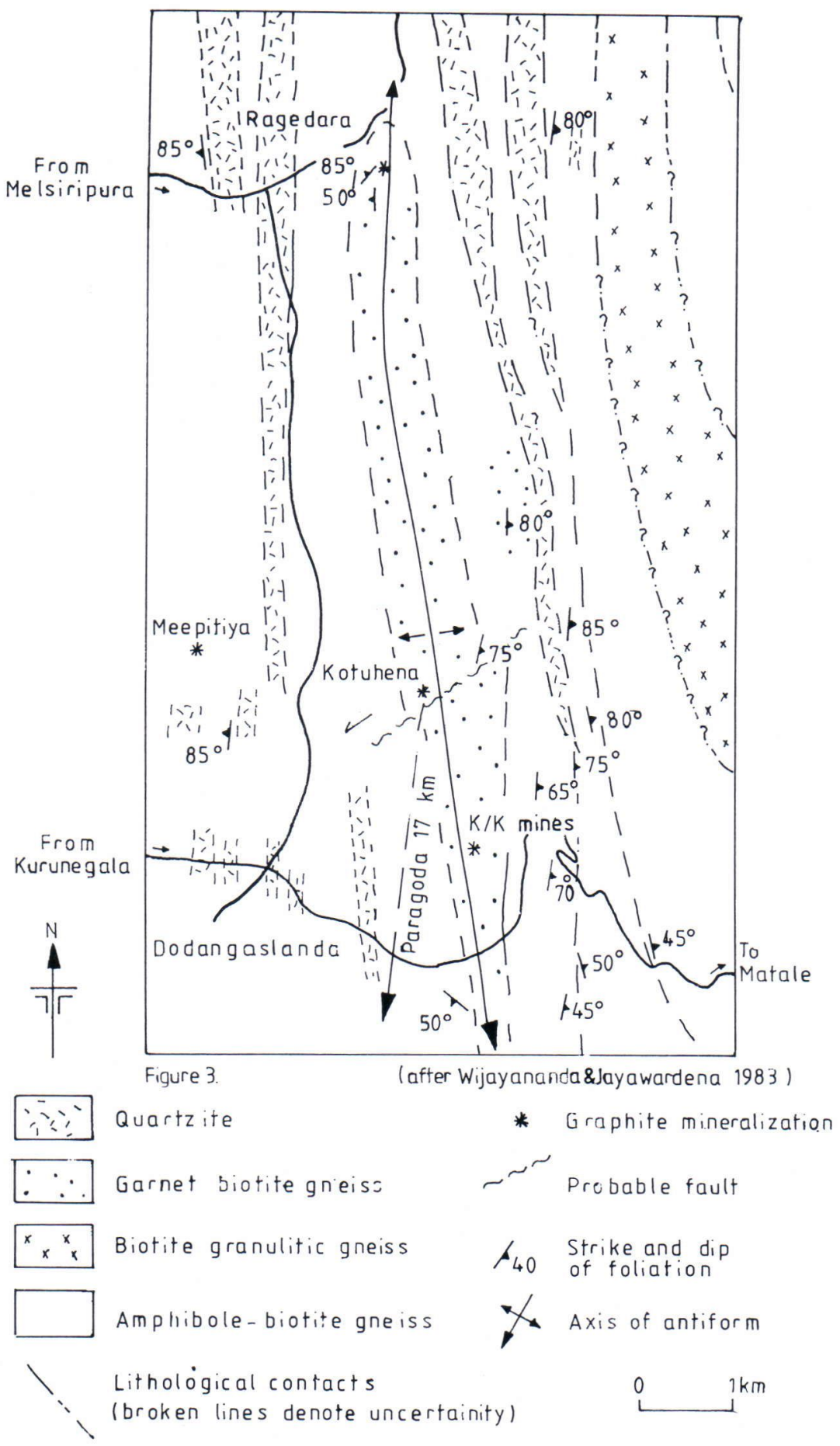

Fig. 3. Geology and structure of the Kahatagaha/Kolongaha and Ragedera Graphite mines. 
with an average dip of $75^{\circ}$ crosscut both limbs of the dome (Fig. 2 b and 3).

\section{Other minerals}

\section{Mica}

The occurrence of mica in Sri Lanka is shown in Fig. 1. According to Coomaraswamy, who carried out a detailed survey of the occurrence of mica in central districts of Sri Lanka in the period 1903-1905, the mode of occurrence of phlogopite, commercially important type of mica, shows the same structural and tectonic control as does graphite, e.g. mica occurs (1) as veins in granulites, (a) parallel to the foliation of rocks, (b) in strike joints and (c) in dip joints; (2) in bands of pyroxene mica rock; (3) along the contact zones of marble and granulite (Coomaraswamy Adm. Report, 1903).

\section{Corundum}

Of the placer gem deposits, corundum has been found in situ in a few localities. In 1903 Coomaraswamy discovered blue sapphires in bands of feldspathic granulite near Tennahena, $3 \mathrm{~km}$ from Talatu Oya- (Fig. 1). These bands showed a mineralogical composition of $64.2 \%$ orthoclase microperthite, $23.5 \%$ oligoclase, $4.7 \%$ biotite and $7.6 \%$ corundum with other heavy minerals (Coomaraswamy 1903). Again in 1904, corundum was discovered as violet pink to purplish hexagonal crystals in two localities in Haputale District on the Ormiston estate, about $330 \mathrm{~m}$ southwest of Dambaketiya trignometrical station and on the Haldumulla estate, $8 \mathrm{~km}$ below Haldumulla (Coomaraswamy 1904). At Haldumulla, it was found in a corundum sillimanite-type rock interlayered with charnockite "probably as bands and lenses."

During the late Processor Sahama's visit to Sri Lanka in 1983, the writer accompanied the professor on a visit to the more recentely discovered occurrences of corundum - the blue sapphires near Polgahawela. Unfortunately, we could not find any sapphires in situ at the time. But the owner of the land reported that blue sapphires had earlier been collected from the comformable pegmatite layers in the charnockitic rocks. It appears that this occurrence is similar to that at Haldumulla where corundum is associated with conformable pegmatitic feldspathic layers in the country rock. Coomaraswamy (1904) observed that the corundum in the corundum-sillimanite-type rock at Haldumulla and in the feldspathic granulite rock at TalatuOya "occurs in columnar hexagonal crystals, while most of that to be got from the gembearing gravels occur in doubly pyramidal crystals."

\section{Lineament tectonics and mineral deposits}

Recent studies on the lineaments (Hatherton et al. 1975; Katz 1978; Vitanage 1983a and $1983 \mathrm{~b}$ ) indicate that some of them, especially the Pre-Gondwana tectonic megafractures, are favourable sites for mineralization, e.g. the Highland/Vijayan boundary zone along Mahaweli Shear Zone I (Fig. 1). In 1971 a large copper-magnetite deposit was discovered by the Geological Survey Department around Seruwila near Trincomalee (Jayawardene 1983). Recent findings of the Geological Survey indicate that this thrust boundary zone warrants examination for new mineral discoveries.

In addition to this major lineament gravity anomalies (Hatherton 1975) suggest at least two major deep discontinuities - a "'second eastern thrust feature'" marked by the steep gravity gradient along the east coast, shear zone No. 3 (Fig. 1). As shown in Fig. 1, the deep fracture zone or thrust marked by the gravity low along the northwestern Vijayan and the Southwest Group is another potential zone for possible mineralization.

Hatherton (1975) also refers to the high hybrid gravity anomalies (high) between Vavu- 
nia and the east coast. Superimposed on these generally high values is a closed high amplitude of about $10 \mathrm{mgal}$ between Vavunia and Keblitigollewa. This anomaly is attributed to either less thick or more basic crust in the VavuniaTrincomalee region. An interesting feature in this area is the unique occurrence of a "'black sands" placer deposit with ilmenite, rutile and zircon that extends for over $10 \mathrm{~km}$ around Pulmoddai beach. The source of these heavy minerals may be the basic rocks of the gravity high because the Mahaweli river sediments are cut off by the Trincomalee submarine canyon. Another narrow gravity high occurs NE of Negombo and extends northwards west of the Tabbowa low towards Mannar. Isolated occurrences of magnetite with barite have been noted along this belt near Pandiiendawa and Wilagedara (Fig. 1). An extensive programme of coredrilling indicated the presence of 5.6 million tonnes of banded iron-ore with barite in a succession of calc-gneiss and quartzite; this is therefore the largest known magnetite iron-ore deposit in Sri Lanka. The investigations also indicated that intensive tectonic activity has broken up the deposit into four blocks with the orebody dipping sharply to depths of 133-166 m (400-500 ft) (Fernando 1970, p. 389).

\section{Groundwater and lineaments}

Recent groundwater investigations by Plancenter, Finland, in the Kandy District in central Sri Lanka (1983-84), and hydrogeological investigations in Matale and Polonnaruwa Districts by Kampsax-Kruger, Denmark (1983), indicate the importance of lineament analysis of the airphotos available and of satellite imagery (Landsat) to the successful localization of deep wells (tube wells) for extracting groundwater from fissured zones along lineaments in hard crystalline Precambrian rocks. The Post-Gondwana lineaments, especially the tensionally opened NW-SE trending discontinuities, seem to be ideal for storing groundwater (Wilbert 1983).

\section{Plate tectonics and oil prospects in northwestern Sri Lanka}

The study of correlation of megalineaments both offshore and onshore in southern India and Sri Lanka and offshore geophysical and deep drilling data on Palk Bay and the Gulf of Mannar indicates that the Sri Lankan mini-plate has been moving away from the Indian Plate very slowly ever since Upper Jurassic Cretaceous times 126 m.y. ago (Katz 1978; Vitanage 1983). Palaeomagnetic measurements carried out by Soviet scientists on cores from the Pesali wells show anticlockwise rotational motion, which accompanied the slow drifting of Sri Lanka away from the Cauvery rift starting in the early Mesozoic.

More recently Curray (1983) and Vitanage (1983) have commented on the possible SSE drift of the Island away from southern India. Curray cites two cases indicating that "Sri Lan$\mathrm{ka}$ is acting as a small mid-plate platelet moving very slowly within and relative to the large Indian Plate'. One is the observation that the offshore sediments of the Bengal Deep Sea Fan off the SSE continental margin are folded and uplifted in a manner suggesting that they are passing into a subduction zone; the other is the observation that the subsequent drifting rates in the Cauvery-Palk Strait in the Gulf of Mannar Basin appear to have accelerated during the Neogene.

Vitanage (1983) has also shown that a series of regional and locally developed lineaments have cut the Sri Lanka miniplate into wedges and blocks. Slow vertical creep along these strike-slip lineaments as a result to the SSE drift of the blocks and the probable resistence of the oceanic crust along the SE subduction zone in the Bay of Bengal has given rise to the anomalous morphological upwarping of the Island 
along an arcuate axis from Galle (southwestern Sri Lanka) to Batticaloa via Nuwara Eliya. This has produced high plains and plateaux with a ring of mountain peaks and young valleys with waterfalls (Fig. 1).

This SSE drift of Sri Lanka should provide a favourable environment, especially because of the high thermal history, for oil and gas generated in the Palk Straits. The results of the three unsuccessful wells drilled at Pesalai (Pesali 1, 2 and 3) by the Soviets and the two exploratory wells drilled by Ceyoil Corporation at Palk Bay and Delft (Fig. 1) show that the offshore area of northwestern Sri Lanka possesses some of the characteristic necessary for commercial accumulation of hydrocarbons. "A more intensive and careful exploration programme will be able to locate the potential oil/gas deposits."

\section{Mineralization in arenas}

As stated earlier with reference to the Central Highland Series, a series of arenas (six) are arranged en echelon around Kandy (Fig. 1 and Fig. $3 \mathrm{c}$ in Vitanage 1972). Close scrutiny of some of these morphological features - double plunging elongated synclinal basins with migmatitic hornblende, microcline biotite gneiss at the centre and pink-feldspar granite bands around the arena rim squeezed down by the typical metasedimentary rocks (quartzites, marble and charnockite granites and gneisses) of the Highland Series shown that they are products of intensive tectonic activity with a highly sheared and faulted unconformable contact zone. In the Teldeniya arena, copper was discovered near the Victoria Dam in 1980 (Vitanage). Detailed mapping of this arena indicates widespread mineralization-enrichment of copper minerals in the basic layers in the nose of the syncline (Ranasooriya 1980). These basic layers contain pyrite, chalcopyrite, bornite, malachite and azurite with $2-5 \%$ dessiminated copper and $0.9 \%$ silver. Another find is the banded iron-ore in quartzites. A detailed exploration programme has not yet been undertaken but indications exist that considerable base metal deposits, especially magnetite, could occur at shallow depths (the rocks around the southern end of the Taldeniya arena regularly attract lightning during afternoon thunder storms. Hence the name - Henagahuwala - the depression created by lightning.

\section{Summary and conclusions}

Field studies from 1901-1905 and more recent field mapping and geophysical surveys show that the occurrence and localization of economic minerals and mineral-bearing rocks, e.g. graphite, mica, copper, magnetite and serpentine, have been intimately controlled by structure and tectonics. The axes and limbs of the anticlinal folds and domes as well as the shear belts (foliation shears) along the foliation and lithological contact have promoted the occurrence of economic mineral deposits in Sri Lanka.

In spite of the availability of a considerable potential of well-trained field geologists and modern facilities for geological, geophysical and geochemical exploration in various Government Departments, Universities and State Corporation, the pace of mineral exploration and field follow-up of discovered mineral deposits e.g. apatite, magnetite and copper along the Highland-Vijayan boundary thrust, have been rather slow (Vitanage 1971). A more aggressive and intensive field and research programme with the co-ordinated effort of all geological personnel in Sri Lanka will aid in the discovery and exploitation of potential mineral deposits of copper, magnetite and oil, especially along the major lineaments and the off-shore Cauvery Basin.

Acknowledgements. The author is grateful to Mr. Wimal Silva for interesting discussions on his research into graphite 
mineralization. I also thank Mr. K. Dunuhappawa for typing the manuscript and Mr. S. M. B. Amunugama and Miss. S. J. Wijesekera for preparing the illustrations. Mr.

\section{References}

Adams, F. D., 1929. The geology of Ceylon. Canadian Jour. Research, Vol. I. 425-511.

Coomaraswamy, A. K., 1903. Adm. Report, Mineral Survey, Part IV, L1-L12.

Coomaraswamy, A. K., 1904. Adm. Report, Mineralogical Survey, Part IV, E1-E22.

Crawford, A. R. \& Oliver, R. L., 1969. Spec. Publ. Geol. Soc. Australia 2, 283-306.

Curray Joseph, R., 1983. Sri Lanka: is it a mid-plate platelet? Abstract. Symposium on the Geology of Sri Lanka, Dept. Geol. Univ. Peradeniya, Sept. 1983.

Erdosh, G., 1970. Geology of the Bogala mine, Ceylon and the origin of the vein-type graphite. Mineral Deposits 5 , 1970, 375-82.

Fernando, L. J. D., 1970. The Geology and Mineral Resources of Ceylon. 38 Mineral Resources Development Series, ESCAP, UN, New York, 381-390.

Geological Survey Map - Mineral Deposits of Sri Lanka 1983. Printed in Australia.

Hatherton, T.; Pattiaratchi, D. B. \& Ranasinghe, V. V. C., 1975. Professional Paper No. 3, Gravity Map of Sri Lanka $1: 1,000,000$. Geological Survey Dept. and Govt. New Zealand, 1-37.

Jayawardena, Dulip, 1983. The Mineral Resources of Sri Lanka (Abstract) Symposium on the geology of Sri Lanka, Peradeniya, Sri Lanka, Dept. of Geol. AGID, CIFEG and UNESCO, Dept. Geol. Univ. Peradeniya, Sri Lanka.

Kapsax-Kruger, 1983. Planning of rural water supply and sanitation programme in Matale and Polonnaruwa Districts (Vol. 4 \& 7) DIDA, Denmark.

$K a t z, M$. B., 1978. Sri Lanka in Gondwanaland and the evolution of the Indian Ocean Geol. Mag. V. 115, 307316.

Plancenter Ltd., 1982 a. Water resources potential study Kandy District, Sri Lanka, Vol. 1 and 2, Plancenter Ltd., Finland.

Plancenter Ltd., 1982 b. Udunuwara water supply feasibility study, Vol 1 and 2. Plancenter Ltd., Finland.

Ranasooriya, S. M. J., 1980. Geology of the southern part
Wijayananda kindly took me and my students around the Kahataga graphite mine.

of Teldeniya arena. Res. Paper for B. Sc. Geology, Dept. Geol. Univ. Peradeniya, 1-26. (Unpubl.)

Silva, K. K. M. W., 1974. Tectonic control of graphite mineralization in Sri Lanka, Geol. Mag. 111, 4. 307312.

Vitanage, P. W., 1959. Geology of the country around Polonnaruwa, Geological Survey Ceylon, Colombo 1-75.

Vitanage, $P$. W., 1968. Geological Map of Polpitiya Tunnel, INGRAS, Polpitiya, Sri Lanka.

Vitanage, P. W., 1972. Post-Precambrian uplifts and regional neotectonic movements in Ceylon. Proc. 24th IGC, 1972, Section 3, Montreal 642-653.

Vitanage, $P$. W., 1980. Geology Map of the copper and magnetic deposits in Victoria area. (unpubl.)

Vitanage, P. W., 1981. Geology and structure of the Kotmale Project area. Vol. 1 and 2, Sir William Halcraw and Partners and CECB, Ceylon 1-59.

Vitanage, P. W., 1982. Importance of detailed morphotectonic and geological studies as a means of predicting potential hazards and problems in tunnelling and site investigations. Proc. 4th Int. Geol. Congress, New Delhi, Vol. IV, Theme 2, p. IV, 203-215.

Vitanage, $P$. W., 1983 a. Site investigations and geological aspects of tunnelling. Seminar on Tunnelling, Faculty of Engineering, University of Peradeniya, Peradeniya, Sri Lanka. (unpubl.)

Vitanage, $P$. W., 1983 b. A regional study of lineaments in Sri Lanka and possible movements of the »Sri LankanMini-Plate» (Abstract). Symposium on the geology of Sri Lanka, Dept. Geol. AGID, CIFEG and UNESCO, Dept. Geol. Univ. Peradeniya, Sri Lanka.

Wadia, D. N., 1943. Rare Earth Minerals in Ceylon rocks. Prof. Paper I, 1943, Dept. Mineralogy, Ceylon, 1-38.

Wijayananda, N. P. \& Jayawardena, D. E. de S., 1983. Some aspects of the geology of graphite mineralization in Sri Lanka, with particular reference to the KahatagahaKolongaha area. Trans. Instu. Min. Metall. (Section B: Appl. Earth. Sci.) 92, 1983, B93-97.

Wilbert, K. V. K., 1983. Pot-Gondwana tectonics of Sri Lanka with special reference to Tabbowa area and Central highlands. Res. Paper, B.Sc. Geology, Dept. Geol. Univ. Peradeniya, Sri Lanka, 1-78. (unpubl.) 